\title{
Effect of Olive-Mill Wastewater Application, Organo-Mineral Fertilization, and Transplanting Date on the Control of Phelipanche ramosa in Open-Field Processing Tomato Crops
}

\author{
Grazia Disciglio, Antonia Carlucci, Annalisa Tarantino, Marcella Michela Giuliani, \\ Anna Gagliardi (D), Laura Frabboni, Angela Libutti ${ }^{(D)}$, Maria Luisa Raimondo, Francesco Lops * \\ and Giuseppe Gatta \\ Department of Agricultural, Food and Environmental Sciences, University of Foggia, 71122 Foggia, Italy; \\ grazia.disciglio@unifg.it (G.D.); antonia.carlucci@unifg.it (A.C.); antonia.carlucci@unifg.it (A.T.); \\ marcella.giuliani@unifg.it (M.M.G.); anna.gagliardi@unifg.it (A.G.); laura.frabboni@unifg.it (L.F.); \\ angela.libutti@unifg.it (A.L.); marialuisa.raimondo@unifg.it (M.L.R.); marialuisa.raimondo@unifg.it (G.G.) \\ * Correspondence: francesco.lops@unifg.it; Tel.: +39-088-158-9321
}

Received: 13 May 2018; Accepted: 7 June 2018; Published: 11 June 2018

\begin{abstract}
Phelipanche ramosa (L) Pomel is a root holoparasitic weed for many crops, particularly for the processing tomato in Italy. In order to integrate the use of chemical methods to control P. ramosa (L.), there has been an increased effort to research alternative methods using natural compounds. In this regard, two experimental trials were set up in an open field in Foggia (southern Italy) during the 2016 spring-summer seasons. The first trial compared two tomato seedling transplanting dates to evaluate the effects on emerged shoots of P. ramosa. The second trial compared six organic compounds added to the soil to control P. ramosa: olive-mill wastewater and five commercial products (Allyl Isothiocyanate ${ }^{\circledR}$, Alfaplus $^{\circledR}$, Radicon ${ }^{\circledR}$, Rhizosum Max ${ }^{\circledR}$, and Kendal Nem ${ }^{\circledR}$ ). An untreated control was also included. The numbers of P. ramosa emerged shoots (branched plants) were significantly lower for the late tomato seedling transplanting date than for the earlier one. All of the organic products tested that were applied to the soil, particularly olive-mill wastewater, Alfaplus ${ }^{\circledR}$, Rhizosum Max ${ }^{\circledR}$, and Kendal $\mathrm{Nem}^{\circledR}$, showed a significant reduction of the P. ramosa infestation of the tomato crop with respect to the untreated control, with a positive effect on the productive parameters.
\end{abstract}

Keywords: organo-mineral fertilizers; olive-mill wastewater; Phelipanche ramosa; tomato crop

\section{Introduction}

The Apulia region (southern Italy) is the most important area for processing tomatoes (Lycopersicon esculentum Mill.), with almost 20,000 hectares [1] grown annually, $90 \%$ of which are located in the agricultural area of Foggia province. Phytoparasitic weeds are destructive parasites for many agricultural crops in the Mediterranean region, eastern Europe, and northern Africa [2]. Phelipanche ramosa (L.) Pomel is the most widespread holoparasitic species that parasitizes tomatoes in the early spring. It scatters seeds in the summer at the end of the tomato growing season, which can also be considered the most damaging for many other dicotyledons. In the last years, this parasite has continuously expanded into new areas which were previously considered to be parasite-free.

The germination of P. ramosa seeds is stimulated by root exudates from the crop hosts, and in the absence of a host, the seeds can remain dormant and viable for 10 years or more. This persistent "seed bank" makes it complex for any crop rotation to be efficient and indicates the need for rigorous prevention of $P$. ramosa seed production for its successful control $[3,4]$. Completely eliminating the 
parasite seed bank in the soil is practically impossible. The seed bank can only be reduced when the new seed input is smaller than the output caused by unsuccessful germination, pathogens, seed predation, or natural death of the seed [5-8]. However, two or three emerged Striga weed plants per $\mathrm{m}^{-2}$ left to seed are enough to keep the seed bank in balance [9].

The early growth stages of parasitic plant development, such as seed germination, host attachment, and tubercle development, are the key phases and ideal targets for the successful management of these weeds. The air and soil temperatures are the main factors that influence the dynamic of host/parasite interaction and development. A probability model based on temperature regimes (mean and maximum) was used to determine whether or not the seeds would germinate under a given climatic regime [10-13]. At supraoptimal temperatures (i.e., over $25^{\circ} \mathrm{C}$ ), O. crenata seeds will not germinate due to the high temperature [14]. Moreover, the optimum temperature for the maximum germination of Orobanche seeds decreases as the level of their water stress increases [15]. On the other hand, temperature and seed water stress are strongly connected with the climatic conditions, which are themselves related to the periods for crop transplanting into the field. In this regard, studies on the modification of host planting dates have reported the indirect effect of temperature on Orobanche and Phelipanche parasitism $[12,16]$.

Different methods for the control of $P$. ramosa have been investigated, including physical, chemical, agronomic, biological, and biotechnological methods. However, when these methods are applied alone, they are often only partially effective and the results are sometimes inconsistent. An integrated and sustained management strategy consisting of different control methods is highly recommended to contain the broomrape weed problem [9,17-20].

In farming systems characterized by low external input, herbicides are largely or entirely avoided, and weeds are suppressed largely through physical and ecological strategies [21]. Therefore, much research has focused on suitable alternative methods, such as the use of organic compounds, for improving weed management [22-25]. Moreover, the practice of organic soil amendment and the use of some compounds of natural origin, such as amino acids, are suitable because they represent a rich source of microorganisms that can suppress plant diseases and phytotoxicity [26-28].

Apulia is the most important region for olive oil production $\left(200,000 t\right.$ year $\left.^{-1}\right)$, and the extraction process from olive fruit produces a large quantity of liquid waste, referred to as olive-mill wastewater. This wastewater, derived from olive oil centrifuge extraction methods, has chemical properties (i.e., organic carbon, potassium, and phosphorus contents) that could increase soil fertility, and their phenolic compounds can act on the germination of seeds $[29,30]$.

In recent years, the use of organic fertilizers or biostimulant compounds has encountered increasing interest in agriculture because they play roles in various soil and plant functions [31]. Some of these compounds of natural origin, such as natural amino acids, were also suggested for use in P. ramosa management strategies in order to inhibit seed germination [22,32].

Brassica green residue crops, incorporated into the soil, suppressed the growth of many weeds [33]. In particular, the inhibitory effect of Brassicas is attributed to its volatile glucosinolates that by themselves are not phytotoxic, but after the enzymatic breakdown of the plant tissue are converted into isothiocyanates and ionic thiocyanates, particularly allyl-, methyl-, benzyl-, and $\beta$-phenylethyl-isothiocyantes [34]. Isothiocynates are strong inhibitors of seed germination $[35,36]$ and can be used as promising bioherbicides or weed suppressants [37].

However, due to the intrinsic diversity of organic compounds, many studies are still necessary in order to increase knowledge of their specific use for P. ramosa control. This study is mainly focused on the use of some organic compounds applied to the soil prior to crop transplanting or during the tomato cycle in order to assess: (i) whether these methods are efficient for P. ramosa control in processing tomatoes cultivated in the open field; and (ii) the effects on the quali-quantitative parameters of the tomato yield. Moreover, to investigate the possible effects of the transplanting period of a processing tomato crop on $P$. ramosa infestation, two transplanting dates were evaluated. 


\section{Results and Discussion}

\subsection{Climate of the Experimental Site}

The main climatic parameters were recorded daily by a meteorological station near the experimental area supplied by the Consorzio per la Bonifica della Capitanata of Foggia province [38] (Figure 1). The mean temperatures increased almost linearly through the season, from $14.8^{\circ} \mathrm{C}$ (for the first week of April) to $26.6^{\circ} \mathrm{C}$ (for the third week of July), and then decreased to $17.7^{\circ} \mathrm{C}$ by the end of September. The summer season of 2016 was very dry, with the effective decade rainfall ranging from $12.7 \mathrm{~mm}$ to $63.2 \mathrm{~mm}$, mainly occurring during the first stage of tomato cultivation (first and second week of May, first week of June, end of tomato cultivation cycle in September). The daily maximum temperature was almost always below $25{ }^{\circ} \mathrm{C}$ from April to mid-May, the period that corresponds to the first stage of the tomato cycle for the early crop (transplanting in April), while it increased to values always higher than $25^{\circ} \mathrm{C}$ from mid-May to September. According to Kebreab and Murdoch (1999) [14], this threshold value represents nonoptimal temperatures for the seed germination of the root holoparasitic weed.

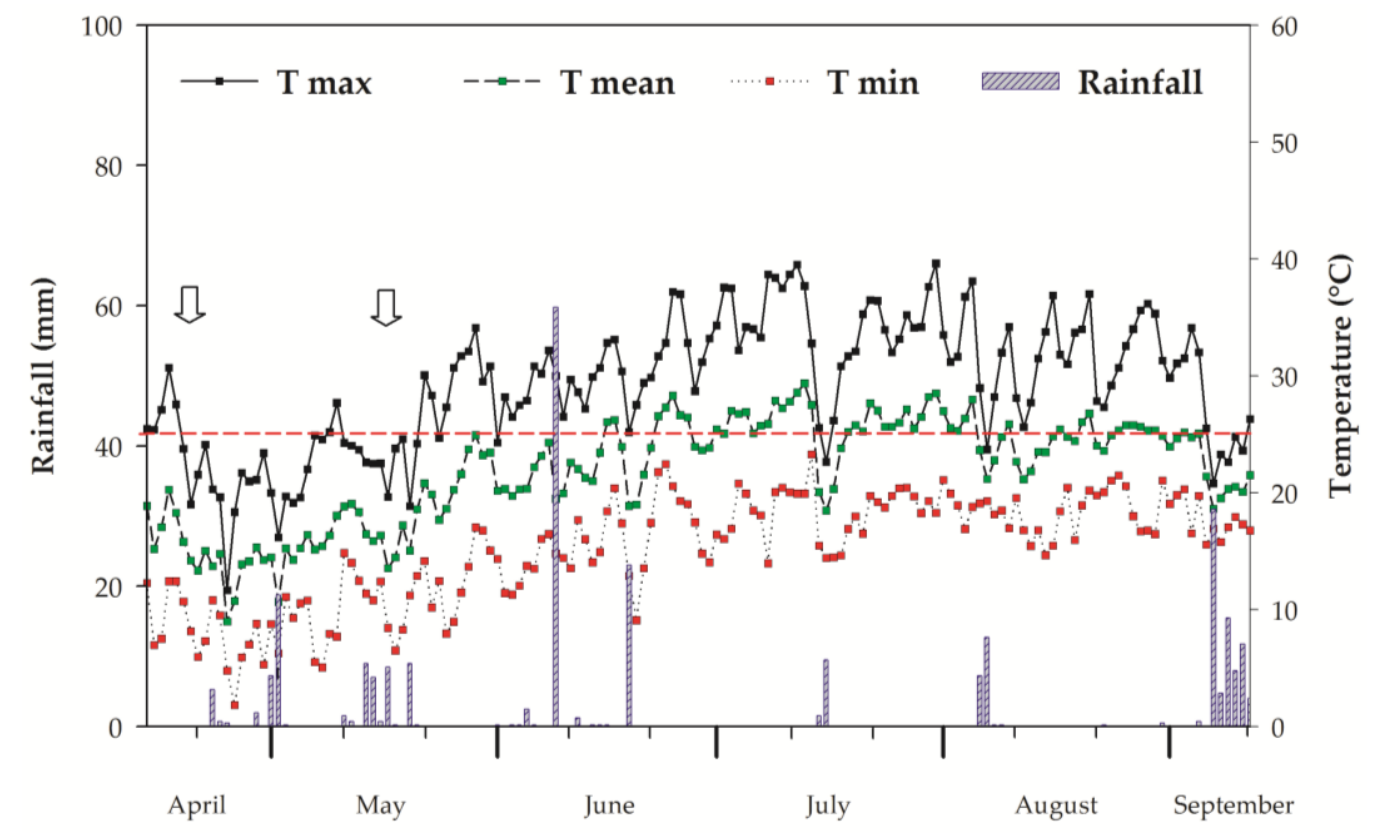

Figure 1. Daily maximum (T max), mean (T mean), and minimum ( $\mathrm{T}$ min) temperatures and rainfall during the two experimental trials. The arrows represent the early transplant of 14 April and the late transplant of 19 May. The red horizontal line indicates the temperature of $25^{\circ} \mathrm{C}$.

\subsection{First Trial Results: Effects of Tomato Transplanting}

As given in Table 1, the number of P. ramosa shoots that emerged at the end of the tomato growth cycle was significantly higher for the early crop $\left(51.4 \mathrm{~m}^{-2}\right)$ than for the late crop $\left(11.7 \mathrm{~m}^{-2}\right)$. This appears to be due to the effects of the different daily fluctuating maximum and mean temperatures that occurred during the early stages of the tomato crop that corresponded to the underground stage of the parasite. In the later crop, the greater amplitude of daily maximum and mean temperatures were suboptimal for seed germination of P. ramosa (Figure 1). This is in agreement with the results from Kebreab and Murdoch (1999) and Murdoch and Kebreab (2005) [14,39,40], who reported that during the conditioning period for the P. ramosa seeds, their survival is limited by higher temperatures at which the process of germination cannot take place. The late seedling transplanting reduced the P. ramosa infestation by $77 \%$ on average. This would give the tomato crop a time advantage over the $P$. ramosa and thereby render it more competitive against this parasitic weed. These data show that 
by delaying the seedling transplanting date to the warmer part of the season (i.e., from 14 April to 19 May), the P. ramosa infestation can be reduced. The early transplanting of the tomato seedling does not allow the rapid development of the tomato crop, as the temperatures favor the germination and competitive growth of P. ramosa. Therefore, the choice of the tomato transplanting date can have a significant influence on the competitive relationship between this crop and the P. ramosa parasite. For this reason, delayed transplanting is suggested as good practice in tomato fields that are known to be infested by P. ramosa.

Table 1. Mean values of emerged branched shoots of Phelipanche ramosa and quanti-qualitative traits of the tomato fruit for the early and late crops at harvesting.

\begin{tabular}{ccc}
\hline Parameters Evaluated & \multicolumn{2}{c}{ Transplanting Dates } \\
\hline & Early crop & Later crop \\
P. ramosa emerged shoots $\left(\mathrm{n} . ~^{-2}\right)$ & $51.4 \pm 3.3^{\mathrm{a}}$ & $11.7 \pm 0.9^{\mathrm{b}}$ \\
Marketable yield $\left(\mathrm{t} \mathrm{ha}^{-1}\right)$ & $64.3 \pm 3.4^{\mathrm{b}}$ & $70.0 \pm 0.9^{\mathrm{a}}$ \\
Total biomass $\left(\mathrm{t} \mathrm{ha}^{-1}\right)$ & $10.4 \pm 0.7^{\mathrm{b}}$ & $13.1 \pm 2.1^{\mathrm{a}}$ \\
Mean fruit weight (g) & $75.1 \pm 6.1^{\mathrm{a}}$ & $76.2^{\mathrm{a}} \pm 2^{\mathrm{a}}$ \\
Dry matter (\%) & $6.4 \pm 1.0^{\mathrm{a}}$ & $5.0 \pm 0.7^{\mathrm{a}}$ \\
Color index $(-)$ & $1.12 \pm 0.1^{\mathrm{a}}$ & $1.15 \pm 0.2^{\mathrm{a}}$ \\
Soluble solids content $\left({ }^{\circ}\right.$ Brix) & $4.1 \pm 0.1^{\mathrm{a}}$ & $4.4 \pm 0.2^{\mathrm{a}}$ \\
$\mathrm{pH}$ & $4.3 \pm 0.1^{\mathrm{a}}$ & $4.2 \pm 0.1^{\mathrm{a}}$ \\
Titratable acidity (g citric acid $100 \mathrm{~mL}^{-1}$ juice) & $0.37 \pm 0.1^{\mathrm{a}}$ & $0.21 \pm 0.1^{\mathrm{a}}$ \\
\hline
\end{tabular}

Data are means \pm standard error $(n=4)$. Data followed by different letters within rows are significantly different $(p<0.05$ according to Tukey's test).

Table 1 also gives the quantitative and qualitative traits related to the tomato yields. The mean marketable yield was significantly higher in the late crop $\left(70.0 \mathrm{t} \mathrm{ha}^{-1}\right)$ compared with the early crop $\left(64.3 \mathrm{t} \mathrm{ha}^{-1}\right)$, with an increased yield for the late crop of $8.9 \%$. Therefore, these data show that the relationship between the tomato marketable yield and P. ramosa infestation is such that the smaller numbers of emerged shoots for the late transplanting resulted in increased marketable yield. In Figure 2, the negative correlation $\left(\mathrm{R}^{2}=0.63\right)$ between $P$. ramosa emerged shoots and marketable yield is reported.

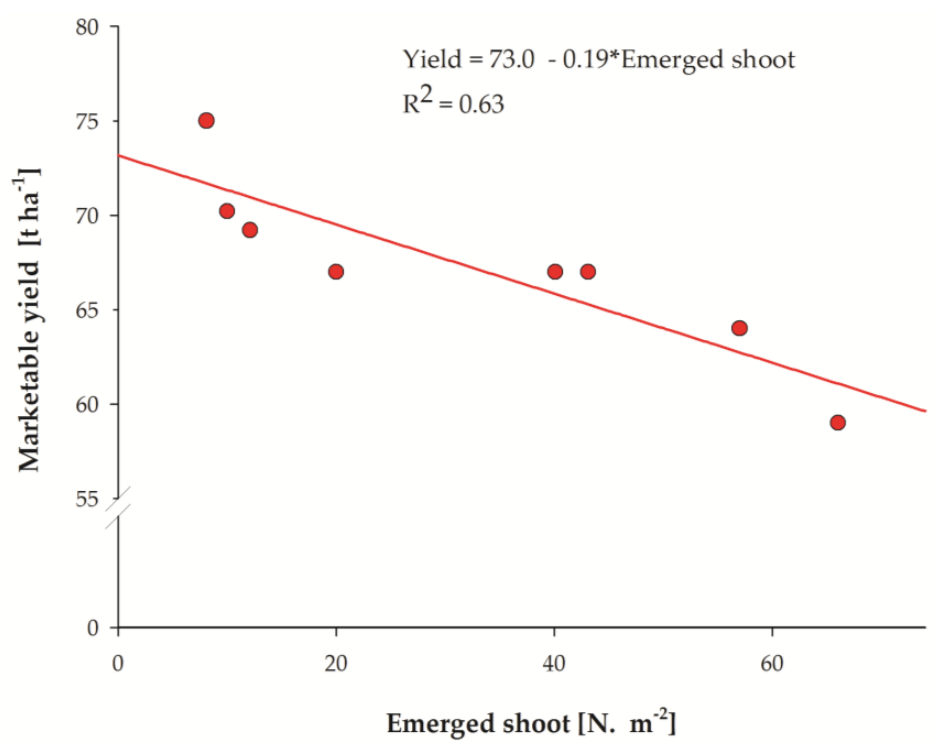

Figure 2. Relationship between tomato marketable yield and number of emerged branched shoots of $P$. ramosa detected at the end of the tomato cycle (harvesting time). 
Parasitism also affected the growth of the host plant, as at the end of tomato cycle, the biomass of the early crop was significantly lower $(20.6 \%)$ than that of the late one (Table 1$)$. On the contrary, no significant differences between the two transplanting dates were found for the tomato quality parameters (Table 1).

\subsection{Second Trial Results: Effect of Organic Compounds}

The first parasitic branched P. ramosa plants emerged above the ground 56 days after transplanting (DAT) for the untreated tomato crop. For all of the treatments, P. ramosa shoots were detected during the growth of the tomato crop at 56,63, and 75 DAT and at the end of the crop cycle (116 DAT). In general, the mean numbers of $P$. ramosa shoots, although with differences among treatments, increased more slowly in the last part of the tomato cycle (from 63 DAT to 116 DAT) because the high temperature values could have resulted in the secondary dormancy induction of parasitic seeds (Figure 3).

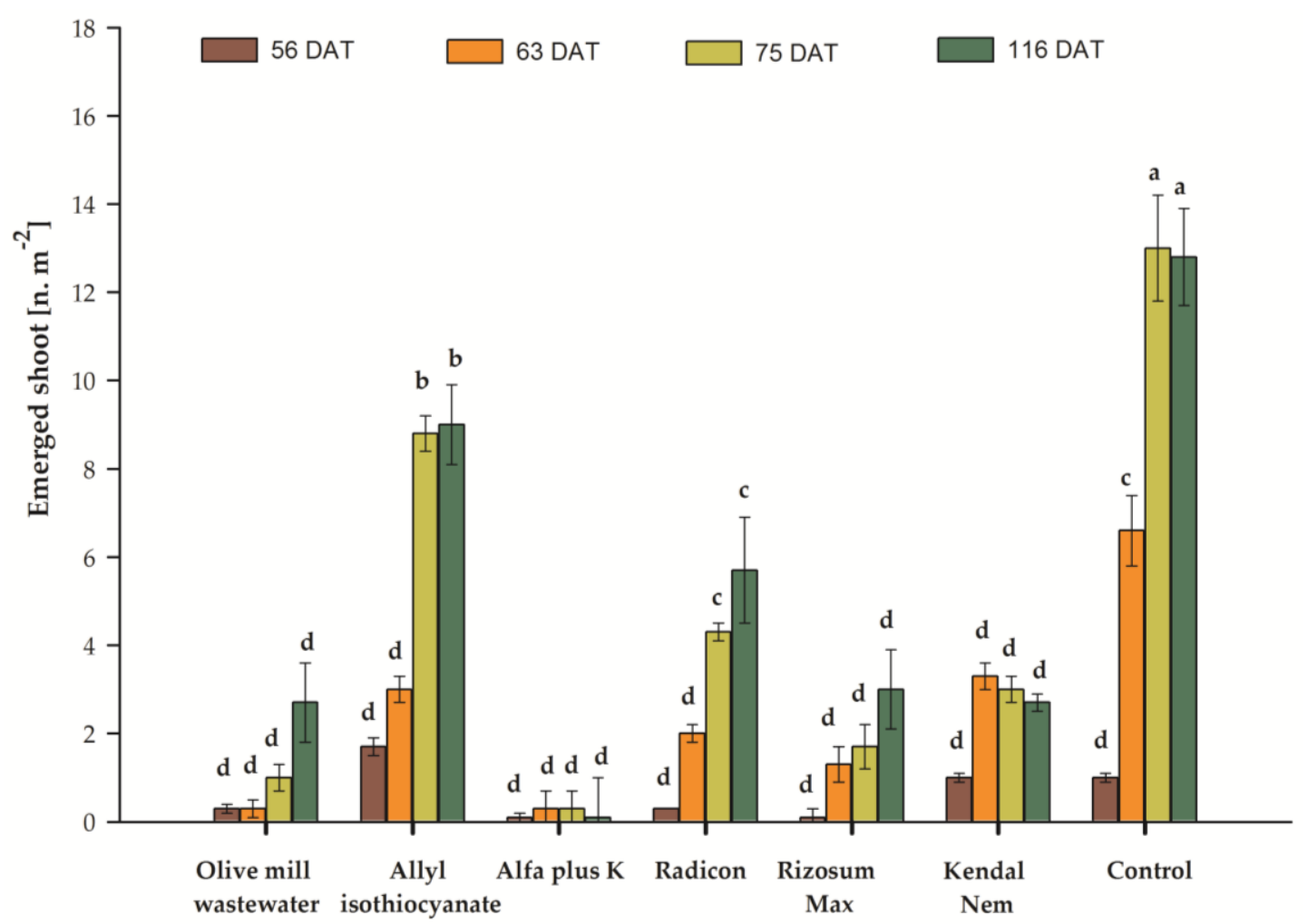

Figure 3. Number of emerged shoots of $P$. ramosa at 56, 63, 75, and 116 days after transplanting (DAT) for the different treatments. Data are means \pm standard error $(n=4)$. Means with different letters $(\mathbf{a}-\mathbf{d})$ are significantly different at $p \leq 0.05$ according to Tukey's test.

Both the olive-mill wastewater and the organo-mineral treatments showed a significant reduction in the emerged shoots of $P$. ramosa compared with the untreated control. Considering the several P. ramosa shoot surveys during the tomato cycle, the values ranged from 0.1 to 8.8 shoots $\mathrm{m}^{-2}$ in the organic compound treatments and from 0.7 to 12.3 shoots $\mathrm{m}^{-2}$ in the control. In particular, at harvest (116 DAT), the emerged shoots in olive-mill wastewater, Alfa plus $\mathrm{K}^{\circledR}$, Rhizosum Max ${ }^{\circledR}$, and Kendal $\mathrm{Nem}^{\circledR}$ treatments varied from 0.1 and 3.0 shoots per $\mathrm{m}^{-2}$. These treatments significantly reduced the number of emerged P. ramosa plants, compared with the untreated control (2-3 vs. 12-13), limiting the production of additional seeds and thus preventing areas not yet contaminated from becoming infested. Many studies [41-43] report that the containment of infested areas and prevention of seed distribution should be major objectives of parasitic weed management strategies, in addition to direct control interventions against the parasites. The significant reduction of the emerged shoots of P. ramosa could 
also be due to additive effects of the mineral compounds, as nitrogen could improve the nutrient status of the tomato crop while producing negative effects for $P$. ramosa seed germination. This is in agreement with earlier studies that reported that mineral nutrients and organic matter introduced into the crop rhizosphere can promote severe physiological disorders for the germination of P. ramosa seeds, with reductions in the number of developing tubercles [44-46].

Allyl Isothiocyanate ${ }^{\circledR}$ treatment showed very poor Phelipanche control compared with other treatments, probably due to inaccurate mechanical fumigant injection into the soil. Effective soil fumigation requires adequate soil preparation, soil moisture control, precise and uniform application, and means to avoid the evaporation of the fumigant [47]. On the other hand, the relatively lower effects obtained by Radicon ${ }^{\circledR}$ could be due to the law of the mineral elements in its composition. Radicon ${ }^{\circledR}$, in respect to other mineral products, contains a lower percentage of nitrogen, which may have an impact on lower soil fertility. The relationship between the production of strigolactones and nutrient availability may explain the prevalence of root parasitic weeds on soils of poor fertility, especially for those low in organic matter or those with a high $\mathrm{pH}$, where nitrogen and available phosphorus are predominantly low.

Table 2 gives the effects of the different experimental treatments on the quantitative and qualitative traits of the processing tomato fruits. The marketable yield was clearly affected by the $P$. ramosa infestation, since the untreated control gave the lowest value $\left(69.40 \mathrm{tha}^{-1}\right)$, which was significantly different from other treatments that gave values ranging between 79.7 and $114.2 \mathrm{t} \mathrm{ha}^{-1}$. The highest marketable yield was for the Alfaplus ${ }^{\circledR}$ treatment, although it was not significantly different from the other treatments with the exception of Radicon ${ }^{\circledR}$, which sowed a lower value. Also, in this second trial, the relationship between the level of $P$. ramosa infestation and crop yield was negative and linear (Yield $=97.44-2.99 \times$ Emerged shoots; $R^{2}=0.78$ ). For the fruit characteristics, such as mean fruit weight, dry matter, color index, $\mathrm{pH}$, and soluble solids content, there were no significant differences seen across these treatments (Table 2). This result is in disagreement with a previous research performed on tomatoes [48]. This could be associated with the much higher number of shoots per tomato plants (108-209) than those of our trial (an estimated maximum value of 40 shoots per host plant) (data not shown).

\section{Materials and Methods}

\subsection{Site Description and Experimental Setup}

During the spring-summer seasons of 2016, two open-field experiments were performed in Foggia ( $41^{\circ} 65^{\prime} \mathrm{N}, 12^{\circ} 48^{\prime} \mathrm{E}$, altitude, $54 \mathrm{~m}$ a.s.l; Apulia region, southern Italy). In the area selected for the trials, the processing tomato crop is very intensively cultivated and infestation by P. ramosa is widespread. The field experiments consisted of two trials: in the first, the effects of two tomato transplanting dates (April and May 2016) on infestation by P. ramosa was evaluated; in the second, the effects of the soil application of olive-mill wastewater produced from the olive oil extraction process and five commercial organo-mineral compounds (Allyl Isothiocyanate ${ }^{\circledR}$, Alfaplus $^{\circledR}$, Radicon ${ }^{\circledR}$, Rhizosum Max ${ }^{\circledR}$, and $\mathrm{Kendal}^{\circledR}$ ) on the control of P. ramosa were evaluated.

\subsubsection{First Trial Setup-Effects of the Tomato Transplanting Date}

The first trial was performed on processing tomato plants (cultivar 'Dres'), belonging to the pear-shaped fruit typology, that were transplanted on two different dates: the early crop on 14 April 2016 and the late crop on 19 May 2016.

The soil was clay-loam (USDA classification) with the following characteristics: total N (Kjeldahl), $1.3 \%$; assimilable $\mathrm{P}_{2} \mathrm{O}_{5}$ (Olsen), 86 ppm; exchangeable $\mathrm{K}_{2} \mathrm{O}, 1430$ ppm; electrical conductivity, $0.9 \mathrm{dS} \mathrm{cm}^{-1} ; \mathrm{pH}, 8.2$; organic matter (Walkley and Black), $1.2 \%$. 
Table 2. Effects of quanti-qualitative traits of the tomato fruits under different treatments (second trial).

\begin{tabular}{|c|c|c|c|c|c|c|c|c|}
\hline \multirow{2}{*}{ Parameter } & Marketable Yield & Plant Biomass & Fruit Weight & Dry Matter & Color Index & Solid Soluble & \multirow{2}{*}{$\mathrm{pH}$} & Titratable Acidity \\
\hline & $\left(\mathrm{tha} \mathbf{a}^{-1}\right)$ & $\left(t \mathrm{ha}^{-1}\right)$ & (g) & $(\% \mathrm{fw})$ & (a/b ratio) & $\left({ }^{\circ}\right.$ Brix $)$ & & (g Citric Acid Per $100 \mathrm{~mL}$ Juice) \\
\hline Olive-mill wastewater & $96.8 \pm 12.0^{\mathrm{ab}}$ & $13.5 \pm 1.8^{b}$ & $80.10 \pm 7.20^{\mathrm{a}}$ & $6.60 \pm 0.40^{\mathrm{a}}$ & $1.10 \pm 0.10^{\mathrm{a}}$ & $5.20 \pm 0.10^{\mathrm{a}}$ & $4.8 \pm 0.2^{\mathrm{a}}$ & $0.45 \pm 0.1^{\mathrm{a}}$ \\
\hline Allyl Isothiocyanate ${ }^{\circledR}$ & $94.3 \pm 8.7^{\mathrm{ab}}$ & $14.0 \pm 0.5^{b}$ & $74.00 \pm 6.07^{\mathrm{a}}$ & $5.71 \pm 0.71^{\mathrm{a}}$ & $1.28 \pm 0.21^{\mathrm{a}}$ & $4.13 \pm 0.09^{\mathrm{a}}$ & $4.5 \pm 0.1^{\mathrm{a}}$ & $0.41 \pm 0.1^{\mathrm{a}}$ \\
\hline Alfaplus ${ }^{\circledR}$ & $114.2 \pm 14.9^{\mathrm{a}}$ & $20.8 \pm 3.5^{\mathrm{a}}$ & $75.54 \pm 3.93^{\mathrm{a}}$ & $6.78 \pm 0.91^{\mathrm{a}}$ & $1.17 \pm 0.11^{\mathrm{a}}$ & $4.30 \pm 0.06^{\mathrm{a}}$ & $4.8 \pm 0.1^{\mathrm{a}}$ & $0.42 \pm 0.2^{\mathrm{a}}$ \\
\hline Radicon $^{\circledR}$ & $79.7 \pm 7.2^{b c}$ & $9.8 \pm 1.3^{c}$ & $81.13 \pm 5.04^{\mathrm{a}}$ & $6.81 \pm 0.80^{\mathrm{a}}$ & $1.22 \pm 0.11^{\mathrm{a}}$ & $3.97 \pm 0.15^{\mathrm{a}}$ & $4.7 \pm 0.2^{\mathrm{a}}$ & $0.35 \pm 0.1^{\mathrm{a}}$ \\
\hline Rhizosum Max ${ }^{\circledR}$ & $106.0 \pm 14.8^{\mathrm{a}}$ & $15.3 \pm 2.9^{b}$ & $71.03 \pm 4.45^{\mathrm{a}}$ & $5.75 \pm 0.70^{\mathrm{a}}$ & $1.15 \pm 0.23$ a & $4,20 \pm 0.17^{a}$ & $4.7 \pm 0.2^{\mathrm{a}}$ & $0.47 \pm 0.2^{\mathrm{a}}$ \\
\hline Kendal Nem ${ }^{\circledR}$ & $88.2 \pm 6.8^{\mathrm{ab}}$ & $18.2 \pm 4.1^{\mathrm{a}}$ & $89.81 \pm 2.96^{\mathrm{a}}$ & $7.55 \pm 0.81^{\mathrm{a}}$ & $1.16 \pm 0.18^{a}$ & $4.50 \pm 0.10^{\mathrm{a}}$ & $4.5 \pm 0.1^{\mathrm{a}}$ & $0.38 \pm 0.1^{\mathrm{a}}$ \\
\hline Control & $69.4 \pm 3.7^{c}$ & $11.4 \pm 2.3^{c}$ & $75.32 \pm 6.22^{\mathrm{a}}$ & $6.53 \pm 0.82^{\mathrm{a}}$ & $1.13 \pm 0.22^{a}$ & $4.25 \pm 0.10^{\mathrm{a}}$ & $4.4 \pm 0.1^{\mathrm{a}}$ & $0.38 \pm 0.2^{\mathrm{a}}$ \\
\hline
\end{tabular}

For each column, statistical differences among mean values are indicated by different letters $(p<0.05)$ according to Turkey's test. 
The tomato seedlings were transplanted into double rows, $0.4 \mathrm{~m}$ apart, which were spaced at 2-m intervals, with the plants positioned $0.3 \mathrm{~m}$ apart within each single row. This provided a theoretical plant density of 3.3 plants $\mathrm{m}^{-2}$. Each seedling transplanting date used a plot of $20 \mathrm{~m}^{2}(2 \times 10 \mathrm{~m})$. A randomized block design was adopted, with four replicates (i.e., plots) for each seedling date. Drip irrigation was used, with the drip lines placed between each pair of plant rows. The water volume for each irrigation varied from $100 \mathrm{~m}^{3} \mathrm{ha}^{-1}$ to $300 \mathrm{~m}^{3} \mathrm{ha}^{-1}$, which depended on the crop growth stage, with a watering interval of 3-4 days. The agricultural management practices applied to these tomato crops during the experimental trials were those commonly adopted by local farmers, such as for fertilizers and for other types of weed and pest control. In this trial, the branched shoots of P. ramosa (hereafter referred to as "shoots") that had emerged from the soil were counted at the end of the tomato cycle (i.e., before tomato harvest) on four sampling areas of $2 \mathrm{~m}^{2}$ for each plot.

The tomato fruits were harvested in the same sampling areas at full-maturity stage, on 30 August 2016 for the early crop and on 12 September 2016 for the late crop, with the marketable yield and total plant biomass measured for each plot. The following major qualitative and quantitative yield parameters were determined on 10 fruits for each plot: mean weight (g); dry-matter content (\% fruit fresh matter); soluble solids content $\left({ }^{\circ} \mathrm{Brix}\right) ; \mathrm{pH}$; and titratable acidity (g citric acid per $100 \mathrm{~mL}$ fresh fruit juice) [49]. The color parameters were also measured using a spectrophometer (CM-700d; Minolta Camera Co. Ltd., Osaka, Japan), using the CIELAB coordinates (i.e., $\mathrm{L}^{*}, \mathrm{a}^{*}, \mathrm{~b}^{*}$ ) on four randomly selected areas of the fruit surface. Here, only the $a^{*} / b^{*}$ ratio is reported, which represents an index that describes the color changes of tomato fruit well [50,51].

\subsubsection{Second Trial Setup-Effects of the Organic Compounds}

The second trial was performed on the same processing tomato cultivar ('Dres'), transplanted on a single day (19 May 2016) in a field in the same area as the first trial. The aim here was to compare six treatments using organo-mineral products such as olive-mill wastewater and five commercial biostimulant products—Allyl Isothiocyanate ${ }^{\circledR}$, Alfaplus ${ }^{\circledR}$, Radicon ${ }^{\circledR}$, Rhizosium $^{\circledR}$, and Kendal ${ }^{\circledR}$-to control P. ramosa in the open field, all of which are allowed products in organic farming. The above treatments were compared with an untreated control. In Table 3, the composition and application mode of the organic products used in the trial are reported.

The soil was clay-loam (USDA classification) with the following characteristics: total $\mathrm{N}$ (Kjeldahl), $1.2 \%$; assimilable $\mathrm{P}_{2} \mathrm{O}_{5}$ (Olsen), 91 ppm; exchangeable $\mathrm{K}_{2} \mathrm{O}, 1230$ ppm; electrical conductivity, $0.8 \mathrm{dS} \mathrm{cm}^{-1} ; \mathrm{pH}, 7.8$; organic matter (Walkley and Black), $1.1 \%$.

A randomized block design with four replicates (i.e., plots) for each treatment was adopted. Each plot was $20 \mathrm{~m}^{2}(2 \times 10 \mathrm{~m})$ and separated by two double rows (4 m apart) of tomato seedlings that were not included in these experimental treatments. The cultivation techniques were the same as those described for the first trial. In this trial, the level of parasite infection was also evaluated by counting the number of emerged main branches from the soil. During the tomato growth cycle, at 56, 63,75 , and 116 (harvest) days after transplanting on four sampling areas of $2 \mathrm{~m}^{2}$ along the two rows of each plot, the emerged P. ramosa shoots were counted.

The tomato fruits were harvested on the same sampling areas, at full maturity stage on 13 September 2016, when the marketable yield and plant biomass were measured. For the qualitative tomato fruit parameters, the same analyses described for the first trial were performed.

\subsection{Statistical Analysis}

To determine whether the data obtained followed normal distributions, Shapiro-Wilk tests were used. The homogeneity of the variance of the whole dataset was assessed using Levene's test. When required, Box-Cox transformations [52] were applied prior to analysis.

The one-way ANOVA procedure was performed according to a randomized block design with four replicates. In the second trial, for the emerged shoot parameter, combined analysis was performed to determine the mean values over the four sampling dates $(56,63,75$, and 116 days after transplanting). 
Table 3. Composition and application mode of the products used in the experiment.

\begin{tabular}{|c|c|c|}
\hline Treatment & Main Characteristics & Application Mode \\
\hline Olive-mill wastewater & $\begin{array}{l}\mathrm{pH}, 5.23 \text {; dry matter, } 62.0\left(\mathrm{~g} \mathrm{~L}^{-1}\right) \text {; total nitrogen, } 1.6\left(\mathrm{Kjeldhal}^{\mathrm{g} \mathrm{L}}{ }^{-1}\right) \text {; } \\
\text { phosphorus, } 185\left(\mathrm{P}_{2} \mathrm{O}_{5}, \mathrm{mg} \mathrm{L}^{-1}\right) \text {; potassium, } 1044\left(\mathrm{~K}_{2} \mathrm{O} ; \mathrm{g} \mathrm{L}^{-1}\right) \text {; total } \\
\text { organic carbon, } 43.3\left(\mathrm{~g} \mathrm{~L}^{-1}\right) ; \text { sodium, } 36\left(\mathrm{mg} \mathrm{L}^{-1}\right) ; \text { calcium, } \\
69\left(\mathrm{mg} \mathrm{L}^{-1}\right) \text {; magnesium, } 90\left(\mathrm{mg} \mathrm{L}^{-1}\right) \text { iron, } 14\left(\mathrm{mg} \mathrm{L}^{-1}\right) \text {. }\end{array}$ & $\begin{array}{l}\text { Applied in the field at } 80 \mathrm{~m}^{3} \mathrm{ha}^{-1} \text {, the maximum amount permitted } \\
\text { to be used in the fields on capable soil (in agreement with Italian Law } \\
\text { No } 574,1996 \text { ) [53] } 40 \text { days before tomato seedling transplantation. }\end{array}$ \\
\hline Allyl Isothiocyanate ${ }^{\circledR}$ (ATC) (Isagro S.p.A.) & $\begin{array}{l}\text { Volatile organo-sulfur compound extracted from Brassica nigra, } \\
\text { Brassica Juncea, and Brassica iric. Groundbreaking soil biofumigant, } \\
\text { the active ingredient of which is Allyl Isothiocyanate }{ }^{\circledR}(96 \% w / w) \text {. }\end{array}$ & $\begin{array}{l}\text { Applied mechanically into the soil } 4 \text { days before tomato seedling } \\
\text { transplantation on } 15 \text { May 2016, at a dose of } 320 \mathrm{~L} \mathrm{ha}^{-1} \text {. }\end{array}$ \\
\hline Alfaplus ${ }^{\circledR}$ (Spagro S.r.l.) & $\begin{array}{l}\text { Organic mineral fertilizer containing organic nitrogen }(3 \%), \\
\text { ammoniacal nitrogen }(13 \%) \text {, organic carbon }(16 \%) \text {, and water-soluble } \\
\text { iron (0.5). Organic components: dried borland and panels. }\end{array}$ & $\begin{array}{l}\text { Applied into the soil } 2 \text { days before the tomato seedling } \\
\text { transplantation, at a dose of } 70 \mathrm{~kg} \mathrm{ha}^{-1} \text {. }\end{array}$ \\
\hline Radicon ${ }^{\circledR}($ Fertek $)$ & $\begin{array}{l}\text { Suspension-solution of humic and fulvic acids, obtained from worm } \\
\text { compost (night crawled), containing organic matter ( } 60 \% \text { of d.m.); } \\
\text { humified organic matter ( } 90 \% \text { of total organic matter); nitrogen }(1 \%) \text {; } \\
\text { rate } \mathrm{C} / \mathrm{N}=4 \text {. }\end{array}$ & $\begin{array}{l}\text { Applied into the soil at transplantation, by soaking the tomato } \\
\text { seedling roots in } 1.5 \% \text { concentrated solution and as fertigation by } \\
\text { drip irrigation on } 28 \text { June and } 20 \text { July at a dose of } 5 \mathrm{~kg} \mathrm{ha}^{-1} \text {. }\end{array}$ \\
\hline Rhizosum Max ${ }^{\circledR}+$ Prosum + Push up $+($ Biosum $)$ & $\begin{array}{l}\text { Rhizosum Max }{ }^{\circledR} \text { is a powder product containing mycorrhize }(2 \%) \\
\text { and rhizosphere bacteria }(\text { Azotobacter vinelandii, Bacillus megaterium, } \\
\text { Pseudomonas putido) }\left(1 \times 10^{10} \mathrm{CFU} \mathrm{g} \mathrm{g}^{-1}\right) \text {. Prosum is a solution of total } \\
\text { nitrogen }(8 \%) \text {, ureic nitrogen }(8 \%) \text {, phosphorus anhydride }(4 \%) \text {, } \\
\text { potassium oxide }(3 \%), \text { iron }(0.08 \%) \text {, and zinc }(0.6 \%) \text {. Push up is a } \\
\text { solution of } \mathrm{N}(15 \%), \mathrm{K}(5.5 \%), \mathrm{Mg}(13.5 \%), \mathrm{Mn}(7.2 \%), \mathrm{Fe}(30 \%) \text {, } \\
\mathrm{S}(40 \%) \text {, amino acids }(60 \%) \text {, vitamin }(30 \%) \text {, alga kelp }(24 \%) \text {, } \\
\text { triacontanol }(0.2 \%) \text {, and Mo }(5 \%) \text {. }\end{array}$ & $\begin{array}{l}\text { Applied into the soil } 2 \text { days before the seedling transplantation, } \\
\text { with tomato roots soaked in concentrated solution }\left(0.84 \mathrm{~g} \mathrm{~L}^{-1}\right) \text {. } \\
\text { Applied by drip irrigation on } 28 \text { June and } 20 \text { July } 2016 \text { at a dose of } \\
75 \mathrm{~kg} \mathrm{ha}^{-1} \text {. }\end{array}$ \\
\hline Kendal Nem ${ }^{\circledR}$ (Valagro) & $\begin{array}{l}\text { Liquid fertilizer, containing total nitrogen }(9 \%) \text {, urea nitrogen }(9 \%) \text {, } \\
\text { potassium oxide }(9 \%) \text {, and GEA } 099 \text { (matrix of vegetal origin). }\end{array}$ & $\begin{array}{l}\text { Applied at transplantation, by soaking the tomato seedling roots in } \\
2.2 \% \text { concentrated solution. } \\
\text { Applied by drip irrigation on } 28 \text { June and } 20 \text { July } 2016 \text { at a dose of } \\
5 \mathrm{~L} \mathrm{ha}^{-1} \text {. }\end{array}$ \\
\hline
\end{tabular}


The statistical significance of the differences in the means was determined using Tukey's honest significance difference post hoc test at the $5 \%$ significance probability level. Bivariate statistical methods were applied to define the relations among marketable yield and emerged shoot parameters. All of the graphical representations were carried out using the SigmaPlot software (Systat Software, Inc., San Jose, CA, USA).

\section{Conclusions}

The results obtained in this study show that agronomic strategies, such as transplanting date and the soil application of organo-mineral compounds, are particularly suitable to promote tomato plant growth and reduce $P$. ramosa infestation.

Based on our experimental data, the late seedling transplanting, from April to May, reduced the $P$. ramosa infestation by $77 \%$ on average. This would give the tomato crop a time advantage over the $P$. ramosa, and thereby make it more competitive against this parasitic weed. Moreover, the outcomes related to the second experimental trials showed that the use of olive-mill wastewater and of commercial organo-mineral products (i.e., Alfaplus ${ }^{\circledR}$, Rhizosum Max $^{\circledR}$, and Kendal Nem ${ }^{\circledR}$ ) applied into the soil can be effective against $P$. ramosa infestation in the field, whereas Allyl Isothiocyanate ${ }^{\circledR}$ and Radicon ${ }^{\circledR}$ treatments showed poorer results. These low performances of Allyl Isothiocyanate ${ }^{\circledR}$ and Radicon ${ }^{\circledR}$ with respect to other mineral products could be due to inaccurate mechanical fumigant injection into the soil and a lower percentage of nitrogen content, respectively.

These methods by themselves are not sufficiently effective to completely eliminate the seed bank of parasitic weeds but can impede or reduce seed production and dispersal. Therefore, more investigation should be carried out with integrated methods for the control of this parasite in processing tomato crops.

In the two experimental trials, the tomato marketable yield was significantly reduced by the higher number of emerged shoots, whereas no significant influences were found for fruit quality characteristics.

Considering that organo-mineral compounds are not normally toxic to humans or to the environment and are metabolized by soil microorganisms, they could represent safe agents for the management of parasitic weeds. The promising and attractive strategy applied to control Phelipanche ramosa needs more research in order to target these control measures most effectively and maintain the seed bank of less infested areas beneath a threshold level of damage.

The advantage of utilizing alternate planting dates and the application of organo-mineral fertilizer could be efficient for integration with other methods for conventional agriculture as well as for possible application in suitable agriculture in organic farming, especially for a gradual and continuing reduction of parasite seed banks in the soil.

Author Contributions: G.D., A.C., G.G., and F.L. contributed to developing the research ideas, conducting the research, analyzing the data, and writing the manuscript. A.T., M.M.G., A.G., L.F., A.L., and M.L.R. provided efforts to field research, lab analysis, and manuscript writing. All authors read and approved the final manuscript.

Acknowledgments: This work was carried out within the project "OROPOMVEG" approved by the Apulia region within the "Linee Guida, 2012-2014" for research and experimentation in agriculture.

Conflicts of Interest: The authors declare no conflict of interest.

\section{References}

1. ISTAT. Electronic Information System on Agriculture and Livestock; Italian National Statistical Institute (ISTAT): Rome, Italy, 2017. Available online: http:/ / agri.istat.it/ (accessed on 20 November 2017).

2. Parker, C.; Riches, C. Parasitic Weeds of the World. Biology and Control; CAB International: Wallingford, UK, 1993; pp. 111-164.

3. Eizenberg, H.; Lande, T.; Achdari, G.; Roichman, A.; Hershenhorn, J. Effect of Egyptian Broomrape (Orobanche aegyptiaca) Seed-Burial Depth on Parasitism Dynamics and Chemical Control in Tomato. Weed Sci. 2007, 55, 152-156. [CrossRef] 
4. Fernández-Aparicio, M.; Reboud, X.; Gibot-Leclerc, S. Broomrape Weeds. Underground Mechanisms of Parasitism and Associated Strategies for their Control: A Review. Front. Plant Sci. 2016, 7, 135. [CrossRef] [PubMed]

5. Grundy, A.C.; Mead, A.; Burston, S. Modelling the emergence response of weed seeds to burial depth: Interactions with seed density, weight and shape. J. Appl. Ecol. 2003, 40, 757-770. [CrossRef]

6. Westerman, P.R.; Wes, J.S.; Van der Kropff, M.J.; Werf, W. Annual losses of weed seeds due to predation in organic cereal fields. J. Appl. Ecol. 2003, 40, 824-836. [CrossRef]

7. Van Mourik, T.A.; Stomph, T.J.; Westerman, P.R. Estimating Striga hermonthica seed mortality under field conditions. Asp. Appl. Biol. 2003, 69, 187-194.

8. Van Mourik, T.A.; Stomph, T.J.; Murfoch, A.J. Purple witchweed (Striga hermonthica) germination and seed bank depletion under different crops, fallow, and bare soil. Weed Biol. Manag. 2011, 11, 100-110. [CrossRef]

9. Van Delft, G.J.; Graves, J.D.; Fitter, A.D.; Pruiksma, M.A. Spatial distribution and population dynamics of Striga hermonthica seeds in maturally infested farm soils. Plant Soil 1997, 195, 1-15. [CrossRef]

10. Eizenberg, H.; Colquhoun, J.B.; Mallory-Smith, C.A. The relationship between temperature and small broomrape (Orobanche minor) parasitism in red clover. Weed Sci. 2004, 52, 735-741. [CrossRef]

11. Eizenberg, H.; Colquhoun, J.B.; Mallory-Smith, C.A. A predictive degree-days model for small broomrape (Orobanche minor) parasitism in red clover in Oregon. Weed Sci. 2005, 53, 37-40. [CrossRef]

12. Ephrath, J.E.; Eizenberg, H. Quantification of the dynamics of Orobanche cumana and Phelipanche aegyptiaca parasitism in confectionery sunflower. Weed Res. 2010, 50, 140-152. [CrossRef]

13. Eizenberg, H.; Hershenhourn, J.; Achdari, G.; Ephrath, J.E. A thermal time model for predicting parasitism of Orobanche cumana in irrigated sunflower-Field validation. Field Crop Res. 2012, 137, 49-55. [CrossRef]

14. Kebreab, E.; Murdoch, A.J. A quantitative model for loss of primary dormancy and induction of secondary dormancy in imbibed seeds of Orobanche spp. J. Exp. Bot. 1999, 50, 211-219. [CrossRef]

15. Kebreab, E.; Murdoch, A.J. The effect of water stress on the temperature range for germination of Orobanche aegyptiaca seeds. Seed Sci. Res. 2000, 10, 127-133. [CrossRef]

16. Grenz, J.H.; Manschadi, A.M.; Uygur, F.N.; Sauerborn, J. Effects of environment and sowing date on the competition between faba bean (Vicia faba) and the parasitic weed Orobanche crenata. Field Crops Res. 2005, 93, 300-313. [CrossRef]

17. Haidar, M.A.; Sidahmad, M.M. Soil solarization and chicken manure for the control of Orobanche crenata and other weeds in Lebanon. Crop Prot. 2000, 19, 169-173. [CrossRef]

18. Habimana, S.; Murthy, K.N.K.; Hatti, V.; Nduwumuremyi, A. Management of Orobanche in field crops. A review. J. Soil Sci. Plant Nutr. 2014, 14, 43-62. [CrossRef]

19. Disciglio, G.; Lops, F.; Carlucci, A.; Gatta, G.; Tarantino, A.; Frabboni, L.; Carriero, F.; Tarantino, E. Effects of different methods to control the parasitic weed Phelipanche ramosa (L.) Pomel in processing tomato crops. Ital. J. Agron. 2016, 11, 39-46. [CrossRef]

20. Lops, F.; Disciglio, G.; Carlucci, A.; Gatta, G.; Frabboni, L.; Tarantino, A.; Tarantino, E. Biological methods to control parasitic weed Phelipanche ramosa L. Pomel in the field tomato Crop. World Acad. Sci. Eng. Technol. Int. J. Biol. Biomol. Agric. Food Biotechnol. Eng. 2017, 11, 264-267.

21. Liebman, M.; Davis, A.S. Integration of soil, crop and weed management in low-external-input farming systems. Weed Res. 2000, 40, 27-47. [CrossRef]

22. Vurro, M.; Boari, B.; Evidente, A.; Andolfi, A.; Zermane, N. Natural metabolites for parasitic weed management. Pest Manag. Sci. 2009, 65, 566-571. [CrossRef] [PubMed]

23. Haidar, M.A.; Sidahmad, M.M. Elemental sulphur and chicken manure for the control of branched broomrape (Orobanche ramosa). Crop Prot. 2006, 25, 47-51. [CrossRef]

24. Litterick, A.M.; Harrier, L.A.; Wallace, P.; Watson, C.A.; Wood, M. The role of uncomposted materials, composts, manures and compost extracts in reducing pest and disease incidence and severity in sustainable temperate agricultural and horticultural crop production. A review. Crit. Rev. Plant Sci. 2004, 23, 453-479, ISSN 0735-2689. [CrossRef]

25. Disciglio, G.; Gatta, G.; Lops, F.; Libutti, A.; Tarantino, A.; Tarantino, E. Effect of biostimulants to control the Phelipanche ramosa L. Pomel in processing tomato crop. World Acad. Sci. Eng. Technol. Int. J. Biol. Biomol. Agric. Food Biotechnol. Eng. 2016, 10, 212-215.

26. Saad, H.; Laor, Y.; Raviv, M.; Medina, S. Land spreading of olive-mill wastewater. Effects on soil microbial activity and potential phytotoxicity. Chemosphere 2007, 66, 75-83. [CrossRef] [PubMed] 
27. Alfano, G.; Lustrato, G.; Lima, G.; Vuitullo, D.; Ranalli, G. Characterization of composted olive-mill wastes to predict potential plant disease suppressiveness. Biol. Control. 2011, 58, 199-207. [CrossRef]

28. Disciglio, G.; Gatta, G.; Libutti, A.; Gagliardi, A.; Carlucci, A.; Lops, F.; Cibelli, F.; Tarantino, A. Effects of irrigation with treated agro-industrial wastewater on soil chemical characteristics and fungal populations during processing tomato crop cycle. J. Soil Sci. Plant Nutr. 2015, 15, 765-780. [CrossRef]

29. Zenjari, B.; Nejmeddine, A. Impact of spreading olive mill wastewater on soil characteristics: Laboratory experiments. Agron. EDP Sci. 2001, 21, 749-755. [CrossRef]

30. Martirani, L.; Giardina, P.; Marzullo, L.; Sannia, G. Reduction of phenol content and toxicity in olive oil mill waste waters with the ligninolytic fungus Pleurotus ostreatus. Water Res. 1996, 130, 1914-1918. [CrossRef]

31. Calvo, P.; Nelson, L.; Kloepper, J.W. Agricultural uses of plant biostimulants. Plant Soil 2014, 383, 3-41. [CrossRef]

32. Vurro, M.; Boari, B.; Pilgeram, A.L.; Sands, D.C. Exogenous aminoacids inhibit seed germination and tubercle formation by Orobanche ramosa (Brooomrape): Potential application for management of parasitic weed. Biol. Control 2005, 36, 258-265. [CrossRef]

33. Petersen, J.; Belz, R.; Walker, F.; Hurle, K. Weed suppression by release of isothiocyanates from turniprape mulch. Agron. J. 2001, 93, 37-43. [CrossRef]

34. Eberlein, C.V.; Morra, M.J.; Guttieri, M.J.; Brown, P.D.; Brown, J. Glucosinolate production by five field-grown Brassica napus cultivars used as green manures. Weed Technol. 1998, 12, 712-718. [CrossRef]

35. Dale, J.E. Decline in phytotoxicity of benzyl isothiocyanates formulated as granules. Weed Sci. 1986, 34, 325-327.

36. Brown, P.D.; Morra, M.J. Hydrolysis products of glucosinolates in Brassica napus tissue as inhibitors of seed germination. Plant Soil 1996, 181, 307-316. [CrossRef]

37. Vaughan, S.F.; Boydston, R.A. Volatile allelochemicals released by crucifer green manures. J. Chem. Ecol. 1997, 23, 2107-2116. [CrossRef]

38. Consorzio per la Bonifica della Capitanata. Available online: www.consorzio.fg.it (accessed on 22 September 2017).

39. Kebreab, E.; Murdoch, A.J. A model of the effects of a wide range of constant and alternating temperatures on seed germination of four Orobanche species. Ann. Bot. 1999, 84, 549-557. [CrossRef]

40. Murdoch, A.J.; Kebreab, E. Temperature dependence of Orobanche germination and implication for the northward spread of Orobanche within Europe. In COST Action 849, Parasitic Plant Management in Sustainable Agriculture, WG1+4 Workshop on Means for Limiting Orobanche Propagation and Dispersal in Agricultural Fields; Newe-Ya'ar Research Center: Rishon LeZion, Israel, 2005; pp. 15-16.

41. Parker, C. Protection of crops against parasitic weeds. Crop. Prot. 1991, 10, 6-22. [CrossRef]

42. Ramaiah, K.V. Control of Striga and Orobanche species-A review. In Proceedings of the 4th ISPFP, Marburg, Germany, August 1987; Weber, H.C., Forstreuter, W., Eds.; Philipps-Universität: Marburg, Germany, 1987; pp. 637-664.

43. Rubiales, D.; Ferandez-Aparicio, M.; Wegmann, K.; Joel, D.M. Revisiting strategies for reducing the seed bank of Orobanche and Phelipanche spp. Weed Res. 2009, 49, 23-33. [CrossRef]

44. Yoneyana, K.; Xie, X.; Kusumoto, D.; Sekimoto, H.; Sugimoto, Y.; Takeuchi, Y.; Yoneyama, K. Nitrogen deficiency as well as phosphorus deficiency in sorghum promotes the production and exudation of 5-deoxystrigol, the host recognition signal for arbuscular mycorrhizal fungi and root parasites. Planta 2007, 227, 125-132. [CrossRef] [PubMed]

45. Jamil, M.; Kanampiu, F.K.; Karaya, H.; Charnikhova, T.; Bouwmeester, H.J. Striga hermonthica parasitum in maize in response to N and P fertilizers. Field Crop Res. 2012, 143, 1-10. [CrossRef]

46. Westwood, J.H.; Foy, C.L. Influence of nitrogen on germination and early development of broom rare (Orobanche spp.). Weed Sci. 1999, 47, 2-7.

47. Goldwasser, Y.; Rodenburg, J. Integrated agronomic management of parasitic weed seed banks. In Parasitic Orobanchaceae; Joel, D.M., Gressel, J., Musselman, J.L., Eds.; Springer: Berlin, Germany, 2013; pp. 393-414.

48. Longo, A.M.C.; Lomonaco, A.; Mauromincale, G. The effect of Phelipanche ramosa infection on the quality of tomato fruit. Weed Res. 2010, 50, 58-66. [CrossRef]

49. AOAC. Official Method of Analysis (No. 934,06); Association of Official Analytical Chemists (AOAC): Washington, DC, USA, 1990.

50. Francis, F.J.; Clydesdale, F.M. Food Colorimetry: Theory and Applications; AVI Publ. Co.: Westport, CT, USA, $1975 ; 477 \mathrm{p}$. 
51. Gatta, G.; Libutti, A.; Gagliardi, A.; Disciglio, G.; Beneduce, L.; d'Antuono, M.; Rendina, M.; Tarantino, E. Effects of treated agro-industrial wastewater irrigation on tomato processing quality. Ital. J. Agron. 2015, 10, 97-100. [CrossRef]

52. Box, G.E.P.; Cox, D.R. An analysis of transformations. J. R. Stat. Soc. Ser. B Methodol. 1964, 26, $211-252$.

53. Italian law (Legge 11 novembre 1996 n.574). Nuove norme in materia di utilizzazione agronomica delle acque di vegetazione e di scarichi dei frantoi oleari. Gazzetta Ufficiale n. 265 del 12 Novembre, 1996. Available online: http:/ / www.camera.it/parlam/leggi/96574.1.htm (accessed on 24 November 2017).

(C) 2018 by the authors. Licensee MDPI, Basel, Switzerland. This article is an open access article distributed under the terms and conditions of the Creative Commons Attribution (CC BY) license (http:/ / creativecommons.org/licenses/by/4.0/). 